IRSH 52 (2007), pp. 243-258 DOI: I0.1017/S0020859007003227

(C) 2007 Internationaal Instituut voor Sociale Geschiedenis

\title{
The Role of Humour in the Process of Collective Identity Formation in Autonomous Social Movement Groups in Contemporary Madrid*
}

\author{
CRistina Flesher Fominaya
}

Summary: This article draws on ethnographic research to analyse the role of humour in the process of collective identity formation within autonomous anticapitalist groups in Madrid. Autonomous groups embrace the principles of horizontality, openness, diversity, participatory democracy, self-organization, and direct action, so defining themselves in contradistinction to more "vertical" movement organizations of the institutional left. The process of collective-identity formation involves both generating a sense of internal cohesion, and projecting an alternative identity. Autonomous groups in Madrid face a double challenge, for they must integrate ideologically heterogeneous activists, and they must define themselves as being alternatives to the much more consolidated groups of the institutional left. I shall analyse the different ways in which humour is used to address both those challenges: to sustain groups over time, to defuse tensions and try to resolve conflict, for myth-making, and to integrate marginal group members. I will also discuss the role humour plays in charismatic leadership and its use in the projection of an alternative political identity in direct actions. Finally, I will discuss the contested nature of humour as a political tool in the context of the Madrid network.

\section{INTRODUCTION}

This article analyses the role of humour in the process of collective identity formation in autonomous anti-globalization activist groups in Madrid. The analysis is based on three years of participant observation in the Madrid network, thirty-two interviews with autonomous activists, and regular monitoring of e-mail lists and alternative media web pages. ${ }^{\mathrm{I}}$

* I would like to thank Lynn Rivas and Amy Hanser for their insightful comments. This research was funded by the National Science Foundation, the German Marshall Fund, and the John L. Simpson Foundation.

I. This analysis draws on findings from a research project for a dissertation in sociology from the University of California, Berkeley, on the praxis and challenges of autonomous social movement groups. Case studies of three autonomous anti-globalization groups formed the core 
Autonomous groups in Madrid actively and explicitly understand their activism as an attempt to create alternative political spaces to represent a departure from institutional left forms of practice. There is a central tension in the movement between actors and groups sharing a more autonomous orientation and those sharing a more institutional or representative orientation. ${ }^{2}$

Drawing on the broader values of the anti-globalization movement, autonomous actors defend a network-based organizational form, underpinned by the principles of self-organization, participatory democracy, autonomy, horizontality, diversity, and direct action. The autonomous activists in Madrid perceive their social movement network as being highly fragmented, highly conflictive, and ideologically heterogeneous. They recognize the superior organizational strength of the institutional left, but tend to characterize the more institutionally minded as being out of touch with the new wave of politics, seeing them as hierarchical and lacking legitimacy.

Political practice that is autonomous, in the sense in which I mean it here, is still relatively new in Madrid and as a result there is no consolidated alternative political culture, such as shared alternative norms about decision-making processes, or any infrastructure on which such politics can rely. Autonomous groups have extremely limited resources, whether physical, financial, personal, legal, or in access to media, so they struggle to carve out a space for themselves in a panorama dominated by party and union politics. One of the resources always available and which they can freely use is humour.

The process of collective identity formation involves both generating a sense of cohesion or "who we are", and as a necessary corollary a sense of otherness or "who we are not". Following Melucci, I understand collective identity formation to be the processes that sustain movement groups between mobilizations, an active construct of the sense of "we-ness" which serves to invite participation and leads to action. ${ }^{3}$ Melucci's emphasis on

of this study, and with rare exceptions I attended all assemblies and most of the social encounters and collective actions and events. My interviews were interactive and covered a broad range of issues related to the activists' political participation, including their specific experiences within each group. They lasted between two and six hours. The overlap of certain activists within the groups provided a comparative understanding of their experiences in these spaces. The chronological overlap of the creation and dissolution of the groups also enabled me to track the "learning curve" of the activists and the shifts in their responses to problems and challenges within the network.

2. For a full discussion of this tension and the characteristics of the social movement network in Madrid see Cristina Flesher Fominaya, "Autonomous Movement and the Institutional Left: Two Approaches in Tension in Madrid's Anti-Globalization Network", in John Karamichas (ed.), New and Alternative Social Movements in Spain: Identity, the Left and Globalising Processes (forthcoming).

3. Melucci discusses collective identity throughout his work, but see especially Alberto Melucci, 
collective identity as a process that is dynamic and ongoing, as opposed to what Snow calls a "product"-based collective identity, is particularly useful for the study of contemporary autonomous movements because of their heterogeneity, emphasis on unity through diversity, and strong antiidentitarian and anti-ideological orientation. ${ }^{4}$

Autonomous groups in Madrid have highly flexible requirements for aesthetics, lifestyle, and even commitment. Unlike identitarian movements (women's, gay, and nationalist for example), autonomous anti-capitalist movements lack a common identity around which to mobilize. Unlike in ideology-based movements, beyond a loosely shared subscription to some general principles there is no common ideology to provide a sense of unity and shared belonging. Instead, autonomous movements must continually regenerate their sense of internal cohesion and oppositional identity. Collective identity is always formed in tension with other actors in the field, be they in the same group, another group, or constituting a target lying outside the movement's own network (the government or capitalism for example).

Autonomous groups in Madrid face a double challenge in their attempt to generate a sense of collective identity: integrating individuals who are ideologically and socio-economically heterogeneous; and defining and projecting an oppositional identity in relation to the much more consolidated groups and platforms of the institutional left. In this article I will analyse the different ways in which humour is used to address both challenges.

Analysing the role of humour in the process of collective identity formation is an important step towards recognizing the place of emotions in sustaining groups, especially in their more latent or internal phases, and in generating mobilization.' Even when analysis of social movements expressly addresses the importance of emotions, humour is often overlooked, with the focus instead on rage, shame, loyalty, joy, or exhilaration. ${ }^{6}$ As this analysis will show, humour can play an important

Nomads of the Present (Philadelphia, PA, 1989), idem, "The Process of Collective Identity", in Hank Johnston and Bert Klandermans (eds), Social Movements and Culture (Minneapolis, MN, 1995), pp. 41-63, and idem, Challenging Codes: Collective Action in the Information Age (Cambridge, 1996).

4. For a discussion of the distinction between product- and process-based collective identity see David Snow, "Collective Identity and Expressive Forms", University of California, Irvine eScholarship Repository (Irvine, CA, 200I), also available at http://repositories.cdlib.org/csd/ OI-07 (last accessed 28 May 2007). For an overview of the use of the concept of collective identity in social movement analysis see Francesca Polletta and James Jasper, "Collective Identity and Social Movements”, Annual Review of Sociology, 27 (2001), pp. 283-305.

5. For a discussion of the role of emotions in social movements see Jeff Goodwin et al., "The Return of the Repressed: The Fall and Rise of Emotions in Social Movement Theory", Mobilization, 5 (2000), pp. 65-84.

6. See Jeff Goodwin et al. (eds), Passionate Politics: Emotions and Social Movements (Chicago, IL, 200I). See too Table I, p. I I, in the same volume. 
part in developing longer-lasting affective ties between group members, fostering a collective identity throughout the movement and projecting an alternative political identity to the public. ${ }^{7}$

The use of humour in autonomous groups is especially significant in Madrid, as it is generally in Spain, because inherently it represents an important departure from the political culture of the institutional left, where humour and ludic activity are frowned upon, being viewed as trivializing the serious struggles activists should be concerned with. Therefore the deliberate use of humour represents a fundamental declaration of political orientation and a distancing from the status quo, even though it is not universally adopted among groups defining themselves as autonomous. Groups in which the majority of activists come from a communist or Marxist-Leninist tradition are less likely to embrace or value the use of humour in mobilization and more likely to embrace a model of confrontation, which partly reflects the influence of the Italian Disobeddienti. Groups more heavily influenced by new social movements, whether feminist, environmentalist, or anti-militarist, and in particular those influenced by groups such as "Reclaim the Streets" are more likely to view humour as a powerfully subversive means of political activism. $^{8}$

Humour has not always been used consciously as a political strategy. Most often it has been used without any awareness of the role it might play in sustaining or even generating collective identity. I will first turn to some of the specific ways in which humour has served to foster, consolidate, and sustain groups, before discussing the conscious use of it as a political strategy. Finally, I will discuss the contested nature of humour as a political tool within the specific context of the Madrid network.

\section{SUSTAINING GROUPS OVER TIME: THE CASE OF THE CSE}

The CSE (European Social Council) was an ambitious experiment in participatory democracy, one that drew its inspiration from the radical democratic spirit that fuels the global anti-capitalist movement. The CSE intended to build a horizontal social movement network in Europe and simultaneously to foster democratic participation in civil society. It started off with an inspirational bang, which initially attracted many autono-

7. This distinction between internal and external uses of humour mirrors Jasper's distinction between affective (longer-term) emotions and reactive or shorter-term responses to contents and events; James Jasper, "The Emotions of Protest: Affective and Reactive Emotions in and around Social Movements", Sociological Forum, I3 (1998), pp. 397-424.

8. Reclaim the Streets (RTS) defines itself as an anti-capitalist dis-organization. RTS is wellknown for creative direct actions that seek to recover public spaces (often colonized for private car use) for public use. They were very important in the British anti-roads movement and have been an important influence on the anti-globalization movement. 
mously oriented activists, but despite the best intentions of its members it was a disastrously ill-conceived and over-ambitious project. Ostensibly, direct action was one of its guiding raisons d'être, yet as the weeks and months dragged by it was unable to generate any significant actions. Even falling far short of such goals, it maintained a loyal following long after many rational reasons for sticking with the project had faded. ${ }^{9}$ One might ask why, in a "movement" context where groups are formed and dissolved with remarkable ease, would anyone remain in a group incapable of action?

Interviews with activists revealed that the environment generated in the assemblies was the key to their decision to remain with the project despite realizing that the chances of meeting their original goals were very slim. ${ }^{10}$ Two main themes emerged from these interviews, the first being that many activists favourably compared their experience in the CSE with the hostile and conflict-ridden environments they experienced in political spaces dominated by the institutional left. The second was that the jokes and banter provided a welcome relief from the gravity of their political work with the institutional left, and that was important to their understanding of what made CSE assemblies such a positive environment. Therefore humour was essential not only to their initial attraction to the group and decision to join, but just as essential to their commitment to remain in it, despite mounting frustrations with its inability to make progress towards its goals. ${ }^{\text {II }}$

About three months after the group's inception, members were asked to evaluate its progress. One activist wrote, "Well, we can't be doing too badly given how much we laugh in assembly". Assemblies were indeed generally quite jolly, and on occasions activists were reduced to tears of laughter. In one assembly, members reported on the responses of activists in the wider network to the question of whether they would be willing to join the CSE. One by one, they reported much the same thing: people were interested, but too busy with their own important work to join just then. As the responses added up, the mood became more and more hilarious,

9. Loyalty outweighing the rational assessment of reasons to stay in a group is discussed in Bruce Fireman and William A. Gamson, "Utilitarian Logic in the Resource Mobilization Perspective", in Mayer N. Zald and John D. McCarthy (eds), The Dynamics of Social Movements (Cambridge, MA, 1979), pp. 8-44.

IO. Interviews: Joaquin, I 5 October 2002; Juan, I 4 November 2002; Lucas, 3 June 2003; Fritzi, 30 June 2003; Nora, 30 September 2003; Carolina, 2 October 2003; Txema, I 9 April 2004; Xurxo, 29 April 2004; Darla, ro May 2004. All the interviews were conducted in Madrid.

I I. See Gary Fine, "Humorous Interaction and the Social Construction of Meaning: Making Sense in a Jocular Vein", Studies in Symbolic Interaction, 4 (1984), pp. 83-10I, for a discussion of humour as a mechanism of definition of self, other, and situation. See also Dolf Zillman and Joanne Cantor, "A Dispositional Theory of Humour and Mirth", in Anthony Chapman and Hugh Foot (eds), Humour and Laughter: Theory, Research and Applications (New York, 1976), on humour aimed at groups with whom people do not empathize. 
and when one member reported that a young activist had said that, "He and the members of his radical group - all four of them - were very concerned with preserving the purity of their acronym", the entire assembly dissolved into fits of laughter. Overall, the responses reflected many of the very characteristics of orthodox left-wing politics these activists were attempting to escape from, and the laughter stemmed from a collective appreciation of the comments' absurdity, and a shared recognition that their own conception of their activism was markedly different. ${ }^{\mathrm{I} 2}$ In this case, humour turned what could have been a disheartening meeting into a collective expression of group identity. In the CSE, then, shared humour created an encouraging environment that provided internal cohesion, generated a sense of "us", helped define "them", and was a major force in sustaining the group despite the emergence of serious frustrations and problems with the project.

\section{NEGOTIATING CONFLICT AND RELEASING TENSION: DEALING WITH THE ACTIVIST FROM HELL}

The EHCG (Horizontal Space Against War) was created in response to the failures of the CSE and another project, the Laboratorio de Desobediencia (Disobedience Lab), to generate direct actions. Centred on anti-militarist direct action, it passed through a rocky initial phase of consolidation. In keeping with autonomous principles, assemblies were open to all comers, and for a time a constant participant was a well-known "activist from hell" named Oriana. ${ }^{\mathrm{I}}$

Oriana was known for her monopolization of "air time", her constant accusations and negative characterizations of other activists, and her sheer imperviousness to any and all attempts to curtail her long-winded interventions. As a new group lacking established rules of procedure, the EHCG had available only limited methodological tools with which to address the "Oriana problem", but even the strategies it did attempt to deploy (such as limiting interventions to two minutes) fell on deaf ears. Confronting her forcefully and directly or asking her to leave would have violated the implicit but deeply internalized norms of acceptable assembly behaviour.

Many of the founding members had placed high hopes in the group and had expended a great deal of energy in convincing others in the network to

I2. This points to the importance of emotions in the motivational framing that stimulates joining movement groups. See Douglas Schrock et al., "Creating Emotional Resonance: Interpersonal Emotion Work and Motivational Framing in a Transgender Community", Social Problems, 5I (2004), pp. 6I-8I. For the need to take emotions into account in frame analysis, see Robert Benford, "An Insider's Critique of the Social Movement Framing Perspective", Sociological Inquiry, 67 (1997), pp. 409-430.

I3. All names are pseudonyms. 
join. Therefore, the stakes for them were high, and Oriana seemed set to leave yet another devastated group in her wake. Tensions were running high. Fortunately, humour had always been characteristic of the group right from the start. Following a long-established ritual, after every assembly a core of activists would retreat to a nearby bar where they would order drinks and unwind after another stressful gathering. Inevitably, talk would turn to Oriana and the jokes would begin. Absurd proposals of how to deal with her were offered up ("Let's just tell everybody but her that the meetings have been switched to Monday"; "Let's slip some soporifics into her drink before the next meeting"); and activists would try to outdo each other by retelling the best (that is to say worst) Oriana story ever, often embellished lavishly, such as "How many people did she knock down in order to get in that press photograph with the actor Javier Bardem?" - an absurd suggestion given how tiny she is.

These sessions were clearly cathartic serving, in Freud's words, to "achieve in a roundabout way the enjoyment of overcoming the enemy". ${ }^{14}$ They reinforced the bonds among the other activists: having survived an assembly with Oriana and lived to tell the tale conferred a strong sense of solidarity, and having survived a great number of such assemblies conferred on the speaker a perverse sort of status. These sessions did little to solve the matter of Oriana's participation, but were crucial in releasing

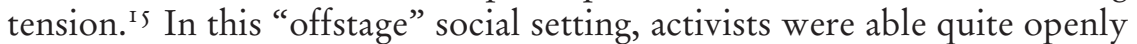
to reveal their feelings of hostility and frustration, and to find comfort in the fact that they were not alone. New participants who joined these sessions were in turn integrated into the group through sharing a common opponent. ${ }^{16}$ This way of using humour to deal with "problem" people was a common feature of the Madrid network.

\section{INTEGRATING MARGINAL MEMBERS: THE BAPTISM OF "LOS PÉNUL",}

After an initial period of uncertainty about the survival of the new political project, the EHCG settled into a relatively firmly consolidated core of

14. Sigmund Freud, Jokes and Their Relation to the Unconscious (New York, 1960), p. I03. I 5. Humour's effectiveness in releasing tension and stress is well documented. See for example, Herbert Lefcourt and Rod Martin, Humor and Life Stress: Antidote to Adversity (New York, I986); Sabina White and Andrew Winzelberg, "Laughter and Stress", Humor, 5 (1992), pp. 343355. Robert Bales and P.E. Slater show how humour serves to maintain relations and achieve goals in task-oriented groups. See Robert Bales and P.E. Slater, "Role Differentiation in Small Decision-Making Groups", in Talcott Parsons and Robert Bales (eds), Family, Socialization and Interaction Process (Glencoe, IL, I955), pp. 259-306.

I6. Research shows that humour serves to help new recruits develop a sense of belonging. See Linda Weiser Friedman and Hershey H. Friedman, "Computer-Oriented HUMor (COHUM): 'I Get It'”, CIS Working Paper Series CIS-2002-10 (New York, 2002). 
activists and a regular rhythm of assemblies and actions. Nevertheless, within the core of activists who participated regularly there were two who did not "fit" easily. There was no single thing that marked them out, just a series of small details adding up to a feeling that they were not being successfully integrated into the group. They were older than the average for the group and, unlike most, were not university-educated, but because of the nature of the group, neither of those factors alone would have set them apart. Their "marginality" stemmed more from the fact that they were resistant to autonomous practices new to them.

For example, one systematically refused to participate in "rounds", a technique whereby the participants/members give their opinions one by one so that everyone's voice was heard. While no-one forced this man to participate, or appeared at all bothered by his refusal, it marked him out as different. Despite repeated requests, neither of them would desist from smoking in the small assembly room. ${ }^{17}$ They took little part in decisionmaking, but were happy to go along with whatever was decided. One group member confessed to me that he did not "quite know what to do about them". All the same they were very well liked, and once an assembly was over they insisted that everyone participate in the ritual post-assembly drinks. They were prodigious drinkers and very generous, eventually managing to inebriate each and every member of the assembly, despite every effort to avoid succumbing to their wiles.

It became clear that the best way to integrate these individuals into the assembly was to designate them organizers of all social events, a role they warmed to. Their legendary ability to drink and make everyone else drink led to the adoption of their nickname "Los Pénul", short for "the penultimates". The name came from their habit of encouraging everyone to have the "penultimate" drink (as opposed to the last one, or último). In time, this was translated (badly!) into English as "before the last one" and members of the assembly would chant this in the bar whenever a member tried to "cry off" and go home. Their christening with a humorous nickname gave them a special status within the group and served to integrate them into the assembly despite the fact that in many ways they did not exactly fit. Humour effectively converted their marginal status into a special status. ${ }^{\mathrm{I}}$

17. Smoke-free assemblies are still strongly resisted in Spain.

I8. Stephenson's study of jokes highlights how they serve to minimize class or status conflict and express common values. See Richard Stephenson, "Conflict and Control Functions of Humor", American Journal of Sociology, 56 (195 I), pp. 569-574. Several theorists propose that humour serves to create, provide structure for, and maintain hierarchies in groups. See for example Rose Coser, "Laughter Among Colleagues: A Study of the Social Functions of Humor among the Staff of a Mental Hospital”, Psychiatry, 23 (1960), pp. 8 I-95; or Lawrence La Fave, "Humor Judgments as a Function of Reference Groups and Identification Classes", in Jeffrey Goldstein and Paul E. McGhee (eds), The Psychology of Humor: Theoretical Perspectives and 
THE ROLE OF HUMOUR IN CHARISMATIC LEADERSHIP: THE CASE OF JUAN

As a "horizontal" group, the EHCG had no formal leaders, but as with most groups it had informal ones. The cohesive force behind the EHCG, at least during its initial phase, was undoubtedly Juan, whose leadership did not derive from having great experience, for there were far more experienced activists in the group. His intelligence and enthusiasm were also qualities likewise shared by many other members. What set Juan apart was his razor-sharp wit, which made people want to be in his company. His humour was often self-deprecating, but he was particularly noted for his skewering of leading figures of the institutional left, and for poking fun at any manifestations of orthodoxy or pedantry in other members of the movement network. One day he flippantly turned a famous historical quote on its head, saying of a leading leftist in the wake of a failed election, "He cries like a social democrat over what he could not defend as a communist". (The original quote was attributed to Sultan Boabdil's mother, who reproached him as they were abandoning Granada: "You cry like a woman over what you could not defend as a man".)

On another occasion, Juan sat in a bar with a group of fellow activists after a frustrating assembly of the Disobedience Lab, a political project dominated by a core of activists from a group called the Nomad University who had a penchant for Italian autonomist discourse. One activist complained morosely, "I don't even know what the hell they are talking about half the time". To which Juan quipped, "Let's go and find those Nomads and break their double articulations" - a pun on the theoretical concept favoured by the group (doble articulación) and the Spanish word for "joints" (articulaciones). The mood instantly changed from despondent to elated as everyone burst out laughing. Juan's e-mails were as entertaining as his interventions in person, and on the rare occasions when he was not present in assembly his absence was felt keenly.

Juan's humour forged a sense of collective identity in a number of ways. It was he who came up with the nickname "Los Pénul" for example. He subjected his fellow assembly members to much good-natured ribbing, and converted their mundane mishaps into entertaining stories, which

Empirical Issues (London [etc.], I972), pp. 195-210. It is interesting to note, therefore, how in this case humour is used to eliminate hierarchies in a group seeking to be non-hierarchical. That is more in line with theories that argue that humour serves as a mechanism of cohesion and integration. See, for example, Linda Francis, "Laughter, the Best Mediation: Humor as Emotion Management in Interaction", Symbolic Interaction, I7 (1994), pp. I47-I63; Karen Vinton, "Humor in the Work Place", Small Group Behavior, 20 (1989), pp. I I-I66. However, I suspect that the support for this approach from the findings of this study stems more from the goal of integration and collective identity formation in these groups than from the fact that humour is a stronger mechanism for integrating than for creating differentiation of status. Research (such as that cited above) shows that it does both. 
served to make them feel special and part of the group. Among other things they reject, autonomous activists tend to dislike obscure, jargon-laden discourse, hierarchical behaviour, orthodox ideologies, cults of personality, sacred cows, and self-promotion whether by groups or individuals. By so often making the butt of his wit the decisions, statements, and actions of individuals on the institutional left, Juan clarified the definition of what the autonomous group was not, fostering a common bond among them and a common barrier against the "other" ${ }^{19}$ In general, the desire to enjoy his humour motivated participation in the group. While his leadership did not stem solely from it, his humour played a crucial part.

\section{MYTH-MAKING: THE FAILED DOUSING OF THE UNKNOWN SOLDIER'S FLAME}

Myths and stories are common to the culture of social movements. ${ }^{20}$ The following story of a disastrously failed action has become legendary within the Madrid social movement network. Its mythical status derives not from the spectacular success of the action, but precisely from its failure and the very absurdity of it. One version of the story, recounted by a participant in the action, is as follows:

The idea was to douse the Unknown Soldier's flame, as a symbol of extinguishing militarism and violence, and of protesting against the war in Iraq, and the plight of everyone who suffers from war and armed conflict. So we get down to the monument, and Juan and Xurxo are the ones who are going to jump over the fence and douse the flame. In order to jump over, they have to step onto a bench. So Xurxo steps onto the bench and "crack" he crunches this homeless man's glasses. The man was sleeping on the bench, but Xurxo hadn't seen his glasses, which were lying there. So the guy gets up and starts yelling, "My glasses! My glasses! You broke my glasses!" So this is supposed to be a clandestine action, right, and there's a police station only a few yards away. So Magda and Ana rush over to the guy and try to calm him down before he alerts the police. "We'll pay for your glasses, we'll fix them. See, there's an opticians, let's go over and see what we can do." They were desperate a) to get the guy to calm down and b) to get away from there. But there was nothing they could do, he just kept yelling and screaming. So, of course, a police officer comes over to see what's the matter, and he joins the whole imbroglio. Meanwhile Juan and Xurxo are crouched by the flame, just out of sight, and are trying to set about dousing it. As Magda, Ana, the homeless guy, and the policeman finally wander off to deal with the guy's glasses, Juan pulls out the fire extinguisher he has brought along. He presses the

19. For a detailed discussion of cohesive outwards-directed humour (jokes whose target is individuals or groups outside the present group) in task-oriented groups see Dawn Robinson and Lynn Smith-Lovin, "Getting A Laugh: Gender, Status, and Humor in Task Discussions”, Social Forces, 80 (200I), pp. I23-I 58.

20. John Lofland, Social Movement Organizations (New York, 1996). 
lever and nothing happens. He keeps pressing, again and again, and - nothing. "That's funny", he says, "it worked perfectly when I tested it before". Xurxo looks at him. "When you tested it before? [...] Give me that thing. Juan this is empty, you've let out all the foam." So after all that, there they are with no extinguisher. They look round to see what they can use but they have nothing. So they start to blow on the flame, as if that's going to do anything! They're puffing and blowing, and of course, nothing. So they give up and climb back down with the empty extinguisher, just as the policeman is coming back. They hightail it out of there, with the guy yelling, "Hey you with the fire extinguisher! Come back here!" ${ }^{21}$

This story was recounted numerous times. Each time it was told to someone new by a member of the group, everyone dissolved into gales of laughter. Soon the story began making the rounds in the network, taking on new details, omitting others. Months later, it was submitted to an antimilitarist web page, in response to a request for activists to send in the best direct action story they had heard. ${ }^{22}$ Some months later, the action was repeated successfully, and was reported with all due solemnity in the alternative media. ${ }^{23}$ However, the action people remember is not the successful one, but the failed one. The power of this story lies in its ability to provoke laughter and a shared sense of identification with the participants in the situation. ${ }^{24}$ The retelling of the story provides a sense of cohesion in the network between activists who embrace non-violent direct action (NVDA) as a form of political practice, far beyond the specific members of the group who initiated the action. It transmits a direct action collective identity across the network in a context where NVDA is a strategy employed by a minority of actors.

So far I have focused on the role of humour when it is not consciously nor explicitly deployed as a strategy to foster collective identity; and when the interaction involved relates to the internal or latent phases of mobilization. Even the fire extinguisher story is not for broader public consumption, and, because the action failed, it was not projected publicly. However, humour played a key role in the conceptualization of direct actions whose intended audience was the general public. Apart from a belief in the subversive power of humour as a strategy of communication,

21. Madrid, 30 October 2004.

22. See the article at http://www.nodo50.org/tortuga/article.php3?id_article $=2554$ (last accessed 29 May 2007). It is also commented on at http://www.antimilitaristas.org/ forum.php3 ?id_article $=1092 \&$ id_forum $=364$ (last accessed 29 May 2007).

23. See www.nodo50.org/tortuga/article.php3?id_article $=2803$ (last accessed 29 May 2007).

24. Fine and de Soucey define joking cultures as sets of humorous references known to group members which are referred to and serve as the basis for further interaction. Joking cultures are retrospective and self-referential. They argue that joking cultures smooth interaction, allow members to share tradition in the name of cohesion, and separate the group from outsiders. See Gary Alan Fine and Michaela de Soucey, "Joking Cultures: Humor Themes as Social Regulation in Group Life”, Humor, I8 (2005), pp. I-22. 
in the specific context of the Madrid network the use of humour in direct action was also a clear declaration of political principles and of an alternative collective identity. The following direct action is perhaps the clearest example of that, as it attempted explicitly to reject the institutional left (representative) model of mobilization and provide instead an autonomous (participatory) alternative.

The classic mobilization form of institutional left-wing actors in Madrid is the protest march, where leaders march at the front with a large banner, and supporters march behind, carrying smaller banners and flags with the acronyms and identifying symbols of their respective parties and unions. Who stands at the front with the banner, and what the banner actually says, are the outcome of lengthy and often highly confrontational negotiations within "unitary" left-wing platforms. The negotiations preceding the march in Madrid on 27 September 2003 to protest against the war in Iraq were no exception. The infighting disgusted some autonomous members of the social movement network, who felt that the entire partisan/representative focus of the march was wrong-headed. They decided to attempt to reclaim the act of protest for the whole public and to embody a critique of the representative model at the same time.

The original idea came from an anti-militarist group in Zaragoza. ${ }^{25}$ After witnessing the "slugfest" within the organizing platform over the wording of the banner, and who would be in the front line of the march (and therefore appear in any media images), they decided to don GrouchoMarx-style noses and glasses and usurp the front line with a completely transparent banner. Activists in Madrid decided to copy the Zaragoza action. On the day of the march, as thousands waited patiently behind the front line of party and union leaders, a small group of activists waited round the corner. As the march approached they simply took the front position with a transparent banner, chanting anti-militarist songs and the words "Pancarta trasparente, une a la gente" [The transparent banner unites the people]. They invited members of the public to join in, and soon the banner had been taken over entirely by people on the street, and more then joined, leaving the official front of the march behind them (and furious). The media ignored the transparent banner, though that mattered little to the activists since the media was not the target audience of the protest; but some people in the crowd were enthusiastic and happy to be given a non-partisan means of expressing their opposition to the war. A short manifesto was given out explaining the action.

Despite the fact that reactions within the movement were mixed and the reaction of the public appeared to be primarily bafflement, those who organized the action deemed it a success. From their perspective, it was an

25. They communicated this at a retreat at La Canal, Spain, Is August 2003. 


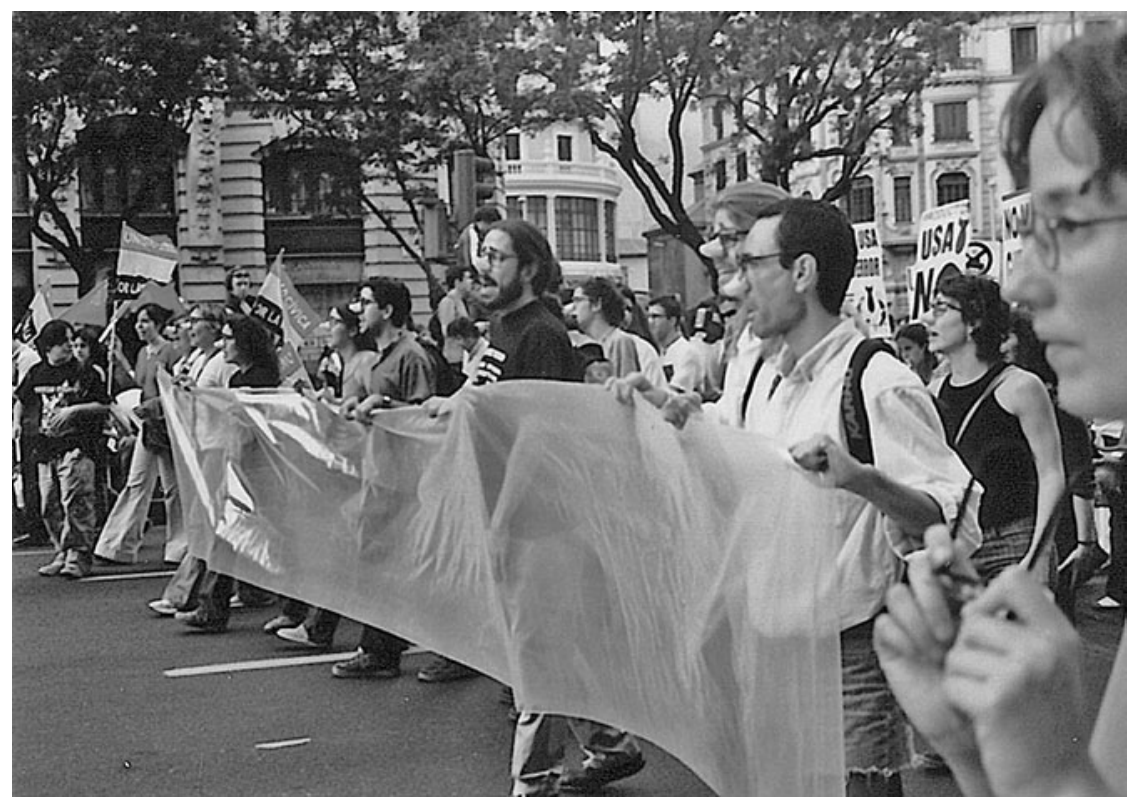

Figure I. Transparent banner action, 27 September, 2003, Madrid

Autonomous activists don "Groucho Marx" noses and glasses and carry a transparent banner to protest against the invasion of Iraq, and to critique the use of protest by the parties and unions of the institutional left as a means of political propaganda. The transparent banner represents a rejection of representative politics and symbolizes a reclaiming of grassroots protest by the public, regardless of political affiliation.

Photographer: Paula Cabildo, Copyleft.

ingenious way simultaneously to express non-partisan opposition to the war, thereby expressing too the autonomous value of grassroots mobilization, and to offer a critique of the representative model of mobilization, which they viewed as hierarchical, outdated, and tending to reinforce existing power structures. Their action clearly represented the projection of an alternative autonomous collective identity (see Figure I).

\section{HUMOUR AS A CONTESTED POLITICAL TOOL}

The recognition of the importance of humour as a means of facilitating integration and group cohesion is still a relatively new concept in Spanish movement circles. The same is true of the recognition of humour's potential for subversion in political activism. The active or strategic use of humour is by no means universal and is not embraced by all movement groups. Generally speaking, groups dominated by activists embracing a Marxist-Leninist ideology (and that includes most of the institutional left) 
were apt to view activism as a serious business. Two of the most frequently heard words in assemblies are "work" and "struggle". The idea that activism can be fun and even funny is new and disconcerting, even for many younger activists who are slowly absorbing broader influences from the global movement.

Two brief representative examples illustrate this. In an assembly of the FST (Transatlantic Social Forum) the agenda included the issue of the need to raise money to pay fines for activists. The meeting was dominated by older activists displaying a pronounced Marxist-Leninist orientation. When one young activist suggested a fund-raising party, normally a common strategy in a resource-poor movement network, the suggestion was met with frowns and headshaking. One man criticized the suggestion, stating gravely, "This issue is much too serious to be trivialized with a party". ${ }^{26}$ The message was clear: parties and politics do not (or should not) mix.

The idea that politics is a serious business holds sway not only with older, more institutionally minded activists; there is resistance to the use of humour even among activists who are both young and avowedly autonomous and who seek ways to break free from the stranglehold they perceive the institutional left maintains over movement activism. That was well illustrated by the reactions of a group of young Spanish activists whom I accompanied to the alternative European Social Forum in London. We spent two days participating in a range of group activities and actions having a strong orientation towards clowning and humorous actions (many facilitated by the Rebel Clown Army). The Spanish activists expressed their discomfort with the heavy emphasis on humour and confessed that they did not "see the point" of the actions. They felt the emphasis on humour detracted from the political weight of these actions, making them "light" versions of what should have been more confrontational acts. They later wrote an article reiterating this impression. ${ }^{27}$

The reaction in movement circles to the transparent banner protest similarly well illustrates the different attitudes to the use of humour in direct action. The action provoked a flurry of commentary on movement websites, revealing a split in opinion. Some activists were furious at the "lack of respect" shown to the leaders of the institutional left, and (rightly) saw the action as a deliberate attempt to throw a spanner in the works of an accord which it had taken hours of infighting to establish. They argued that "idiotic" actions were lost on the public and trivialized the important struggles that were worth fighting for. ${ }^{28}$ In one interview a young

26. FST Assembly, Madrid, 8 October 2002.

27. "Espacios autónomos en Londres, I4-I7 de octubre de 2004", available at http:// www.nodo50.org/tortuga/article.php3 ?id_article $=823 \&$ var_recherche $=$ espacios+autonomos+ londres\#forum233 (last accessed 29 May 2007).

28. Comments retrieved from ACP/Indymedia, acp.sindominio.net/.../09/28/2130217\& threshold $=0 \&$ commentsort $=0 \&$ mode $=$ thread\&pid $=\mathrm{I} 2$ (last accessed Io June 2006). 
anarchist activist said, "We'll never win the revolution through art, creative demonstrations, and all that crap." 29

Such examples show that resistance to the idea that humour might be appropriate, let alone a potentially powerful political tool, is quite entrenched in some parts of the movement network. The authority and legitimacy of the institutional left platforms in Madrid, and their leaders, rests on their seriousness and their perceived commitment to hard work and struggle. These characteristics are inextricably linked to their collective political identity, which makes them vulnerable to the subversive power of humour-based critique. The contested nature of humour as a political tool demonstrates the importance of its active use by some autonomous groups as a means of clearly projecting an alternative political collective identity.

While I have concentrated in this article on the positive effects of humour on the process of collective identity formation, humour can work against that goal, too. Once autonomous groups become consolidated, it can be difficult for new members to be integrated. Not understanding an in-joke, or not knowing why a certain nickname is funny, can be alienating for newcomers. The EHCG, for example, provided such a relaxed environment that newcomers to assemblies might have felt they were at a dinner party thrown by close friends, rather than an open political assembly. In such circumstances, established group members need to work hard to ensure that newcomers see the jokes and can share in the revelry. Humorous actions can misfire when the general public does not see the joke. Such was the case with the transparent banner action. Knowing your audience and framing your message accordingly is essential to any successful communication, and humorous direct actions are no exception.

\section{CONCLUSION}

This discussion makes clear that humour can play a significant role in generating a sense of common identification and solidarity, defining and critiquing the "opposition", integrating new and marginal group members, releasing tension and negotiating conflict, and expressing an alternative opposing political identity. In heterogeneous groups lacking a common "product"-based identity or shared ideology, it can serve as a crucial resource in the process of collective identity formation.

Paying attention to humour and to emotions in general can help explain the emergence and trajectories of social movement groups, particularly those not easily explained using structural or cognitive theoretical approaches. Autonomous groups are resource poor and lack a strong identity and ideology around which to mobilize. Focusing on the role of

29. Interview with Carmen, Madrid, 23 September 2002. 
humour in both their internal dynamics and the projection of their political identity to the public can provide important insights into the cultural processes that build and sustain movements.

The examples in this article show that the creation of boundaries between opposing groups rests not only on cognitive definitions but is conditioned by emotional responses also. The role of humour in the process of collective identity formation for these autonomous groups clearly had both cognitive components (clear definitions of practices and attitudes open to critique; associated with the opponent) and affective components (wanting to participate in the group or feeling integrated, for example). Integrating an awareness of the importance of emotions into our analysis of social movements, including humour, can but enrich our comprehension of their emergence, trajectories, and decline. 